\title{
Size Selectivity, Injury, Handling Time, and Determinants of Initial Hooking Mortality in Recreational Angling for Northern Pike: the Influence of Type and Size of Bait
}

\author{
Robert ArLinghaus* \\ Department of Biology and Ecology of Fishes, Leibniz-Institute of Freshwater Ecology and Inland Fisheries, \\ Müggelseedamm 310, 12587 Berlin, Germany; and Inland Fisheries Management Laboratory, \\ Institute of Animal Sciences, Faculty of Agriculture and Horticulture, Humboldt-University of Berlin, \\ Invalidenstrasse 42 by Philippstrasse 13, 10115 Berlin, Germany \\ THOMAS KLEFOTH \\ Inland Fisheries Management Laboratory, Institute of Animal Sciences, Faculty of Agriculture and \\ Horticulture, Humboldt-University of Berlin, Invalidenstrasse 42 by Philippstrasse 13, \\ 10115 Berlin, Germany \\ AlexANDER KoBler \\ Faculty of Agricultural Sciences, University of Hohenheim (300), 70593 Stuttgart, Germany
}

STEVen J. COOKe

Fish Ecology and Conservation Physiology Laboratory, Department of Biology, Carleton University, 1125 Colonel By Drive, Ottawa, Ontario K1S 5B6, Canada

\begin{abstract}
We examined the relationship between bait and lure size and type and body size, injury, and handling time for northern pike Esox lucius, an important recreational fisheries resource in much of North America and Europe. Bait type and size were significantly related to the size of fish captured and hooking location. Hooking in critical locations (i.e., gills, gullet) was more likely to occur with natural bait, soft plastic shads and jigs, and spoons than with spinners and wobblers (i.e., plugs). Small baits $(<75 \mathrm{~mm})$ were more likely to hook the fish in the gills and less likely to hook the fish in the upper jaw than larger baits. It took longer to remove hooks from gills than from other hooking locations. Frequency of bleeding was related to depth of hooking but was unrelated to fish size, bait type, bait size, or fishing method. Initial mortality of northern pike was low (mean $\pm 95 \%$ confidence interval $=2.4 \pm 1.5 \%$ ), and hooking mortality was significantly related to the level of bleeding as a proxy for severity of injury. Results of this study suggest that using large artificial lures and large natural baits can effectively reduce the incidence of hooking small northern pike (i.e., those that are sublegal in some jurisdictions). However, the use of natural bait can also result in a higher incidence of deep hooking, which in turn increases the likelihood of injury and bleeding. This study revealed the complexity associated with using bait and lure restrictions to complement standard harvest regulations in northern pike recreational fisheries.
\end{abstract}

Controversy exists over the effectiveness of harvest regulations in recreational fisheries management (Paukert et al. 2001; Radomski et al. 2001). Such controversy arises, in part, because some fish will die after release (Munoeke and Childress 1994; Bartholomew and Bohnsack 2005) and others will experience a suite of sublethal disturbances and injuries that may affect long-term growth and fitness (Cooke et al. 2002; Arlinghaus et al. 2007a). Catch-and-release angling is a necessary component of all harvest regulations and a practice voluntarily conducted by many anglers

\footnotetext{
* Corresponding author: arlinghaus@igb-berlin.de
}

Received November 7, 2006; accepted April 27, 2007 Published online January 24, 2008
(Arlinghaus 2007; Arlinghaus et al. 2007a), for example, in specialized fisheries for esocid species such as the muskellunge Esox masquinongy (Fayram 2003). To complement standard harvest regulations and reduce undesirable effects associated with angling (e.g., injury through deep hooking), there is a need to provide information on handling procedures and terminal gear configurations that minimize injury and other potentially detrimental effects (e.g., physiological disruptions) on the fish to be released (Cooke and Schramm 2007). Appropriate gear choice and bait type and size might reduce injury and enable more selective exploitation of the target species, thereby contributing to more effective fisheries management (Wilde et al. 2003) and improved fish welfare (Cooke and Schramm 
2007; Arlinghaus et al. 2007b). This may also result in developing more efficient ecotechnologies intended to improve water quality through the enhancement and conservation of exploited piscivorous fish stocks, also known as biomanipulation (Benndorf 1995; Mehner et al. 2004). Biomanipulation refers to a reduction of planktivores in eutrophic water bodies that is obtained by establishing and protecting an abundant piscivorous fish community followed by an increase in the abundance and size of herbivorous zooplankton (mainly large Daphnia species). In this context, protection of northern pike E. lucius as a major top predator in many European water bodies is advisable (Benndorf 1995; Mehner et al. 2004).

The conservation of northern pike is an important fishery management goal because this species is a popular but highly vulnerable target for many freshwater and brackish-water anglers around the world (Weithman and Anderson 1978; Mosindy et al. 1987; Pierce et al. 1995; Paukert et al. 2001; Arlinghaus and Mehner 2004). Vulnerability of northern pike to angling is related not only to high angler interest (Paukert et al. 2001; Arlinghaus and Mehner 2004), but also to the pronounced association of these fish with submergent and emergent macrophytes in the littoral zone (Craig 1996). This habitat selection facilitates identification of northern pike habitat by shore and boat anglers, particularly in small lakes, and may induce high exploitation rates (Mosindy et al. 1987). Northern pike behavior and prey attack strategies might also play a role in the high vulnerability of this species to angling (Weithman and Anderson 1978). To develop effective conservation measures for northern pike management, a need exists to provide baseline information on issues such as size selectivity of different lures and baits and level of injury associated with different bait types and sizes. This information is needed to support scientifically defensible bait regulations or special harvest regulations such as high minimum size limits or restrictive daily bag limits for northern pike. Such regulations are, for example, common in biomanipulated lakes in Germany to protect northern pike from overexploitation (Benndorf 1995) but have never been evaluated in terms of their efficiency. Many of these regulations also involve regulatory catch-and-release angling.

For northern pike, available reports on the impact of catch-and-release angling are inconsistent in terms of the level of hooking mortality and injury. Low hooking mortality rates in some studies or treatment groups (e.g., hook size and type) ranged from zero (Burkholder 1992; Burr 1998) to several percent (e.g., Weithman and Anderson 1978: 1.7\%; Schwalme and Mackay 1985: 3\%; Burkholder 1992: 4.8\%; DuBois et al. 1994:
$<1 \%$ ). In contrast, other studies have documented higher hooking mortality rates (e.g., Falk and Gillman 1975: 5.3-10.5\%; Grimm 1981 [cited in Tomcko 1997]: up to $12.5 \%$; DuBois et al. 1994 : up to $33 \%$; also Newman and Storck 1986: $4.5-11.3 \%$ in tiger muskellunge $E$. lucius $\times E$. masquinongy). Level of catch-and-release angling mortality in northern pike depends on type of hook, hooking location, and type of handling (DuBois et al. 1994). Deep hooking was among the most important factors of catch-and-release angling mortality in northern pike, and type of hook was found to be a primary determinant of hooking location and level of bleeding (DuBois et al. 1994). However, it is unclear to what extent different bait or lure types and sizes determine hooking location in northern pike. The only study available on this topic (Burkholder 1992) examined the effect of different hook types on hooking location and bleeding probability in northern pike. The author reported that bleeding was more likely for fish caught with a small treble hook than for those captured on lures with double treble hooks, large treble hooks, or a single hook.

In this study, we investigated the influence of bait type and size on the characteristics of catch and injury in northern pike. The size of prey that predatory fish can consume is directly related to predator length and gape (Mittelbach and Persson 1998). As some northern pike anglers typically use comparatively large natural bait or lures, this pattern might facilitate positive sizeselective exploitation (Orsi et al. 1993; Wilde et al. 2003; Cooke et al. 2005). Hence, it may be possible to reduce the hooking incidence of sublegal-sized fish (i.e., those smaller than the legal limit) or to target specific size-classes of northern pike by using the appropriate bait and lure sizes and types (Wilde et al. 2003). Achieving this would be compatible with claims by Armstrong et al. (1990), who stated that appropriate fisheries management requires fishing gears to catch target-length fish while enabling nontarget-length individuals to escape unharmed.

The objectives of this study were to assess (1) the effect of lure type and size and bait type and size on the size of northern pike captured by rod and reel as well as the distribution of legal- and sublegal-sized fish in the catch; (2) the effect of lure or bait type and size on hooking location, injury (amount of bleeding), and handling time (time of hook removal); and (3) the factors associated with initial hooking mortality. We hypothesized that northern pike size captured, hooking location, injury, and handling time would be a function of lure and bait types and sizes. Based on studies in a variety of species, it was expected that (1) the size of northern pike captured would be positively related to 
lure or bait size (Wilde et al. 2003); (2) the amount of deep hooking would be inversely related to lure or bait size (Cooke et al. 2005); (3) natural bait would be more deeply ingested than artificial baits (Pauley and Thomas 1993); (4) time of hook removal and bleeding frequency would be higher for deeply hooked fish (DuBois et al. 1994); and (5) bleeding would increase initial mortality in northern pike (DuBois et al. 1994).

\section{Methods}

Study area.-The study was carried out in Germany and Canada within two mesotrophic lakes with naturally reproducing northern pike populations. The German component of the study was conducted at Lake Kleiner Döllnsee, about $80 \mathrm{~km}$ northeast of Berlin in the northeastern lowlands of Germany $\left(52^{\circ} 59^{\prime} 32.1^{\prime \prime} \mathrm{N}\right.$, $13^{\circ} 34^{\prime} 46.5^{\prime \prime} \mathrm{E}$ ). This natural lake (surface area $=25 \mathrm{ha}$ ) has a mean depth of $4.1 \mathrm{~m}$ (maximum depth $=7.8 \mathrm{~m}$ ), is mesotrophic to slightly eutrophic, and is dimictic. Dense reed belts (bulrushes Typha spp., common reeds Phragmites spp.) are characteristic habitats in this lake together with several areas where submerged macrophytes flourish (see Klefoth 2007 and Kobler 2007 for details). Eckmann (1995) reported 10 different fish species in this lake; Klefoth (2007) and Kobler (2007) reported two additional species. Among the top predators, northern pike and Eurasian perch Perca fluviatilis are abundant and European eel Anguilla anguilla and European catfish Silurus glanis are also present. However, abundance of the latter two species is low (Eckmann 1995) and both species have been introduced through stocking for scientific purposes (Klefoth 2007; Kobler 2007). Experimental angling took place from June to September 2005.

The Canadian part of the study was conducted at Lake Opinicon, a shallow (mean depth $=4.5 \mathrm{~m}$ ), mesotrophic natural lake in eastern Ontario $\left(44^{\circ} 33^{\prime} 56.0^{\prime \prime} \mathrm{N}, 76^{\circ} 19^{\prime} 23.6^{\prime \prime} \mathrm{W}\right)$. Compared with Lake Kleiner Döllnsee, this lake is large (787 ha) and dimictic. Emerged macrophytes are sparse, but submerged macrophytes are very abundant in all parts except the deepest areas of the lake. The fish species community is characterized by abundant populations of northern pike, largemouth bass Micropterus salmoides, smallmouth bass M. dolomieu, rock bass Ambloplites rupestris, bluegill Lepomis macrochirus, pumpkinseeds $L$. gibbosus, and small cyprinids (Keast et al. 1978). Lake Opinicon was angled experimentally in May 2006.

Northern pike populations in both study lakes are moderately exploited by hook-and-line fishing. Whereas public fishing pressure seems to be moderate for northern pike in Lake Opinicon, public fishing is prohibited in Lake Kleiner Döllnsee. However, in Lake
Kleiner Döllnsee during recent years, there has been some sampling by fyke nets, gillnetting, and angling conducted for scientific inquiry by members of the Leibniz-Institute of Freshwater Ecology and Inland Fisheries. Lake Opinicon has no size limit for northern pike but does have a bag limit, and there is a seasonal closure between mid-November and mid-May. Both lakes contained self-sustaining populations of northern pike.

Northern pike angling.-The gear and angling methods used to capture northern pike were intended to reflect common tactics used by anglers (e.g., barbed hooks; Tomcko 1997). Fish were captured in both lakes by medium-action pike rods (spinning and bait casting) and multifilament (16.3-kg test) or monofilament $(4.5-\mathrm{kg}$ test) line. After a northern pike was hooked, the fish was landed as quickly as possible by a knotless landing net or rubber net or by hand.

A variety of angling methods were used. Artificial lures were actively fished by casting and trolling from a boat. Natural bait was passively fished from the boat and the shoreline. Experimental anglers were instructed to follow their general angling style but were encouraged to apply a variety of methods and bait or lure types and sizes throughout their fishing day. The following artificial lure types, representing a number of different manufacturers, were used during this study: spinners, spoons, wobblers (also known as hard baits, crank baits, or plugs), soft plastic baits (jig heads with soft plastic shads), or natural bait (dead roach Rutilus rutilus, perch, or bream Abramis brama). A variety of bait or lure sizes was used in the study (hereafter, the term "bait" encompasses both artificial lures and natural bait unless otherwise stated).

All artificial lures were fished with at least one treble hook. Some soft plastic jigs and shads were fished with a single hook and one (small shads) or two (large shads) treble hooks. There was no effort to standardize hook sizes across all baits, as the purpose of this study was to look at typical baits used in northern pike angling and their impact on the size of fish captured, hooking location, and injury. Artificial baits were attached to a short leader of steel (about $40 \mathrm{~cm}$ ) to avoid losing deeply hooked fish. The only weight on the line was from the weight of the artificial lure. All hooks were barbed.

Natural bait was fished by attaching a $40-\mathrm{cm}$ steel leader to a swivel. A small float together with a $5-\mathrm{g}$, egg-shaped lead sinker held the dead fish in a particular water depth chosen by the angler. Each bait was equipped with two treble hooks, one in the dorsal region and one in the pectoral region. Each angler was instructed to strike (i.e., set the hook) immediately after the bite was detected to avoid artificially increasing 
deep hooking due to fish swallowing the natural bait. Some active fishing took also place with natural bait attached to a system of two treble hooks (Drachkovitch system). The bulk of the fishing effort was exerted by the first three authors of this paper and a technician, all of which were experienced northern pike anglers. Some other experienced northern pike anglers were also recruited.

Data recording.-Each angler was provided with extensive instruction before the initiation of angling activity and was supplied with measuring tools and a diary in which to record information. Total number of hours fished with either artificial lures or natural bait was determined. At the time of fish capture, the following data were recorded: bait type and total length (size) of the bait excluding hook length; hooking location (upper jaw, lower jaw, both upper and lower jaw, gills, gullet, or external along the side of the fish); bleeding (present or absent); and fish total length (TL; nearest $\mathrm{mm}$ ) and weight (nearest g). Presence of bleeding was used as a proxy for severity of injury. On a subsample of fish captured in Lake Opinicon, the time required to remove the hook (i.e., air exposure duration for a fish that is released after hook removal without being photographed) was assessed beginning with the first attempt to unhook a fish until the hook was removed.

When a northern pike was deeply hooked or hooked in the gills, no effort was made to unhook the fish with long-nosed pliers through the mouth region. Instead, jaw spreaders and a long wire cutter (to protect hands) were used to cut the shank of the hook, leaving the barbed piece of the hook inside the fish; this allowed the angler to retrieve the terminal tackle and bait. Hence, hooks and lures that were deeply ingested were not left inside the fish. If the fish was hooked in the gills, a similar procedure was applied by carefully cutting the shank of the hook through the gill arches. No fish was hooked in the stomach. After unhooking, northern pike were placed into a cooler filled with fresh lake water or into a live well integrated into the fishing boat constantly supplied with lake water. If a fish lost equilibrium, it was observed for $1 \mathrm{~h}$ to determine initial mortality. This type of hooking mortality measures the proportion of northern pike landed that are recognizably dead (i.e., no opercular movement) or that die after a brief holding period (up to $1 \mathrm{~h}$ ) in the live well (Munoeke and Childress 1994). If fish were alive after the 1-h observation period, they were released. Although it is known that initial hooking mortality rates underestimate total hooking mortality (Wilde 1998), this approach was used because of our concern that crowding in nets and pens during a long postrelease observation period (e.g., $24 \mathrm{~h}$ ) could artificially inflate hooking mortality. Personal experi- ences have indicated that northern pike become quickly stressed in cages or pens, and there were no drainable ponds available to use as alternative holding facilities for observing delayed mortalities for longer periods after release. Also, we were primarily interested in the causes of initial hooking mortality assuming that significant variables of initial hooking mortality would likely also influence total hooking mortality. All data recording was done by the primary researchers.

Statistical analyses.-One-way analysis of variance (ANOVA) was used to test for differences in size of captured northern pike and hook removal times among bait types. Dependent variables were analyzed for normal distribution (Kolmogorov-Smirnov test) and homogeneity of variances (Levene's test). In case of deviation from homogeneity of variances, Dunnett's T3 post hoc test was used; otherwise a Tukey's post hoc test was applied. Contingency table analysis was used for categorical variables to determine the relation between, for example, hooking location and presence of bleeding or presence of bleeding and initial mortality (categorized as either dead or alive). Bait sizes were separated into three categories $(<75,75-150$, and $\geq 150 \mathrm{~mm}$ ) to assess differences in size of captured northern pike (ANOVA) and hooking location among bait size categories ( $\chi^{2}$ tests). The combined influence of bait type and size on the size of fish captured was assessed using two-way ANOVA. To investigate the relationship between bait type and size on the number of sublegal-sized northern pike captured, the sample was classified as either sublegal $(<500 \mathrm{~mm}$ TL) or legal ( $\geq 500 \mathrm{~mm}$ TL). The $500-\mathrm{mm}$ threshold was used because it constitutes an upper standard in German northern pike recreational angling and is common elsewhere in North America (Paukert et al. 2001).

Logistic regression was used to analyze the effect of a series of independent variables on dichotomous categorical dependent variables: bleeding $(1=$ yes; $0=$ no) and initial mortality $(1=$ yes; $0=$ no). In the former case, the following variables were tested: fish size, bait size, bait type, hooking location, and angling method (passive, casting, trolling). In the latter case, the same variables were tested, but presence of bleeding was included as a categorical independent variable. Hooking locations were categorized as either critical (gills, gullet; coded as 1) or noncritical (upper and lower jaw, external; coded as 0 ). An estimate of initial hooking mortality ( $\pm 95 \%$ confidence interval $[\mathrm{CI}])$ was calculated using the formulae presented in Wilde (2003) uncorrected for control mortality rates. All statistical analyses were conducted with the Statistical Package for the Social Sciences version 9.0.1 at a type-1 error probability $\alpha$ of 0.05 . 
A

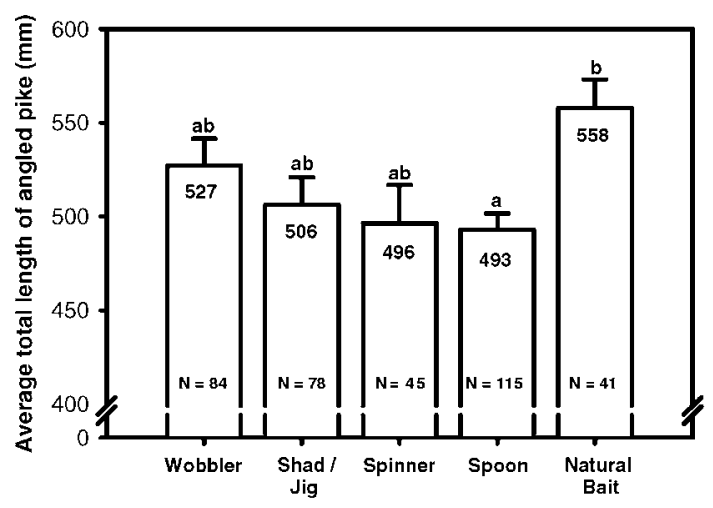

Bait Type

B

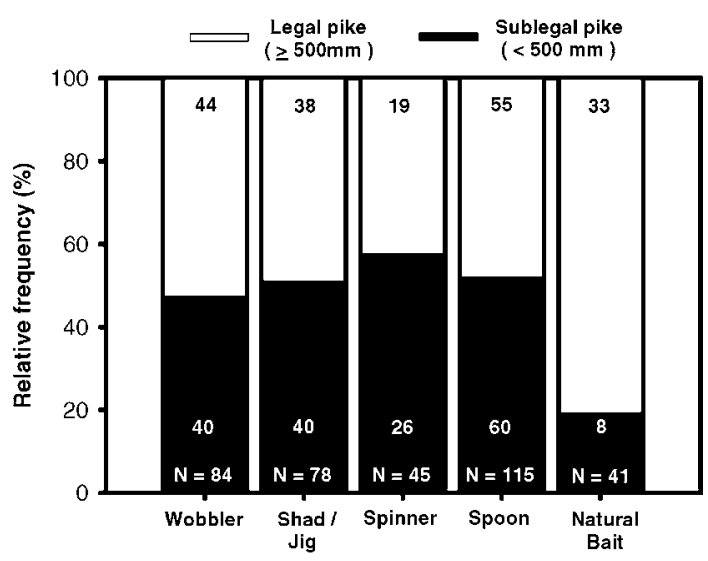

Bait Type

FIGURE 1.-Relation between bait type and (A) average size $(+\mathrm{SE})$ of angled northern pike in Lake Kleiner Döllnsee, Germany, and Lake Opinicon, Ontario, Canada (bars sharing the same letters are not significantly different; $N=$ sample size; numbers within the bars are actual values), or (B) relative frequency $(\%)$ of legal- and sublegal-sized northern pike.

\section{Results}

\section{Descriptive Data}

We angled 415 northern pike, and TLs were obtained from 399 individuals. Fish ranged in length between 252 and $1,020 \mathrm{~mm}$ TL. Average $( \pm \mathrm{SE})$ size and body mass was $512 \pm 6 \mathrm{~mm}$ TL $(N=399)$ and $1,030 \pm 57 \mathrm{~g}(N=267$; no weight data were recorded in Lake Opinicon). Most of the fish were sampled in Germany (65.1\%), and the remainder was sampled in Canada (34.9\%). The size of northern pike captured did not differ between Lakes Kleiner Döllnsee and Opinicon $(t=1.64, \mathrm{df}=397, P=0.10)$. Within Lake
Kleiner Döllnsee, size of fish captured did not differ among months (assessed from June to September; ANOVA: $\left.F_{5,261}=1.02, P=0.41\right)$. There was no significant relationship between capture method (passive versus active casting versus trolling) and size of fish captured $\left(F_{2,372}=2.84, P=0.20\right)$. The mean ( $\pm \mathrm{SE}$ ) catch per unit effort of all artificial lures combined $(0.21 \pm 0.03$ fish/angling-hour) was almost twice as high as that of natural bait $(0.13 \pm 0.04$ fish/ angling-hour), but this difference was not significant $(t$ $=1.66$, $\mathrm{df}=196, P=0.098)$. Northern pike less than $500 \mathrm{~mm}$ TL (sublegal) comprised $49.1 \%$ of the sample. There were no differences in the distribution of legal versus sublegal northern pike in the catch in Canada and Germany $\left(\chi^{2}=0.669, \mathrm{df}=1, P=0.41\right)$.

\section{Relation between Bait Type or Size and Fish Size}

Bait type was significantly related to the size of the northern pike captured (ANOVA: $F_{4,358}=2.93, P=$ 0.02). The size of fish captured on natural bait was greater than that of fish captured on spoons (Dunnett's T3 post hoc test: $P=0.004$ ); all other comparisons of fish size across bait types were not significant $(P>0.05$; Figure 1A). Moreover, whereas the percentage of legalsized fish captured on all artificial baits was roughly $50 \%$, a greater proportion $(80.5 \%)$ of all fish captured on natural bait was of legal size $\left(\chi^{2}=20.46, \mathrm{df}=4, P<\right.$ 0.001 ; Figure 1B). There were no differences across the artificial lures used (Figure 1A) and a similar proportion of legal-sized fish was captured (Figure 1B), despite the fact that the average size of the artificial lures differed substantially among lure types (mean $\pm \mathrm{SD}$; spinners: $86.5 \pm 17.0 \mathrm{~mm}$; spoons: $78.1 \pm 29.3 \mathrm{~mm}$; soft plastic shads or jigs: $131.9 \pm 45.3 \mathrm{~mm}$; wobblers: $124.5 \pm$ $40.5 \mathrm{~mm}$; natural baits: $158.8 \pm 37.6 \mathrm{~mm}$ ). Overall, differences in size of captured fish were negligible among the different artificial lure types, as evidenced by a significant two-way ANOVA with bait type and size (categorical form) as factors $(F=2.55$, total $\mathrm{df}=351, P$ $=0.02$ ). In this analysis, bait type was not related to the size of fish captured $(F=0.85, \mathrm{df}=4, P=0.497$ ), whereas the size of bait was related to fish size $(F=5.54$, $\mathrm{df}=2, P=0.04)$. The bait type $\times$ bait size interaction was not significant $(F=1.28, \mathrm{df}=7, P=0.271$ ).

Across all lures and baits used, the size of captured northern pike was positively related to bait size. Size of captured fish increased for bait sizes of at least $150 \mathrm{~mm}$ (ANOVA: $F_{2,357}=9.95, P<0.001$; Dunnett's T3 post hoc test for comparison between $75-150$ - and $<75-\mathrm{mm}$ lures: $P>0.05$; Figure 2A), as did the percentage of legal-sized fish in the catch $\left(\chi^{2}=16.52, \mathrm{df}=2, P<\right.$ 0.001; Figure 2B). In comparing bait sizes less than 75 and $75-150 \mathrm{~mm}$, there were no differences in the size 
or the percentage of legal-sized fish in the catch (Figure 2; all $P>0.05)$.

\section{Relation between Bait Type or Size and Hooking Location and Injury}

Both bait type $\left(\chi^{2}=52.59, \mathrm{df}=20, P<0.001\right)$ and size $\left(\chi^{2}=20.80\right.$, $\left.\mathrm{df}=10, P=0.01\right)$ were related to hooking location in northern pike. Across all lure types, most fish $(\sim 75 \%)$ were hooked in noncritical areas, such as the upper and lower jaws (Table 1). The following hooking locations were either underrepresented or overrepresented across the different bait types (Table 1): spinners were overrepresented in the lower jaw; spoons were underrepresented in the upper jaw and the gullet and overrepresented in the gills; soft plastic shads and jigs were overrepresented in the gullet and the upper jaw but underrepresented in gills; and wobblers were overrepresented in the external hooking location. Finally, natural bait was more likely to be deeply ingested than all other bait types; $15.4 \%$ of the northern pike captured on natural bait were hooked in the gullet.

Hooking location was also related to size of the bait (Table 2). Small baits $(<75 \mathrm{~mm})$ were more likely to hook the fish in the gills and less likely to hook the fish in the upper jaw, whereas medium-sized baits were less likely to hook the gills. Most hooking locations encompassed noncritical areas across the three bait size categories analyzed.

Time needed to remove the hooks was a function of hook location (ANOVA: $F_{4,100}=13.4, P<0.001$ ). It took longer to remove the hooks in fish that were hooked deeply, such as in the gills (Dunnett's T3 post hoc tests: $P<0.01$ for all comparisons except with upper and lower jaw combined; Figure 3). Also, fish that were hooked in the upper and lower jaws simultaneously required more time to be unhooked. These differences were significant in comparing this group with fish that were only hooked in the upper jaw (Dunnett's T3 post hoc tests: $P=0.048$ ).

The probability that a fish would bleed after angling was unrelated to fish size, bait type, bait size, and fishing method. The only significant factor was hooking location $\left(\chi^{2}=53.74\right.$, df $=9, P<0.001$, $82.6 \%$ correctly classified cases. Deeply hooked fish (e.g., gills or gullet) bled more often than those hooked in noncritical locations or externally $\left(\chi^{2}=62.66, \mathrm{df}=\right.$ $5, P<0.001$; Figure 4 ). In fact, only $28.6 \%$ of fish that were hooked in the gills and $37.5 \%$ of those hooked in the gullet did not bleed at all.

\section{Determinants of Initial Mortality}

Of 415 captured fish, 10 died within $1 \mathrm{~h}$ after capture (initial mortality rate mean $\pm 95 \% \mathrm{CI}=2.4 \pm 1.5 \%$ ).
A

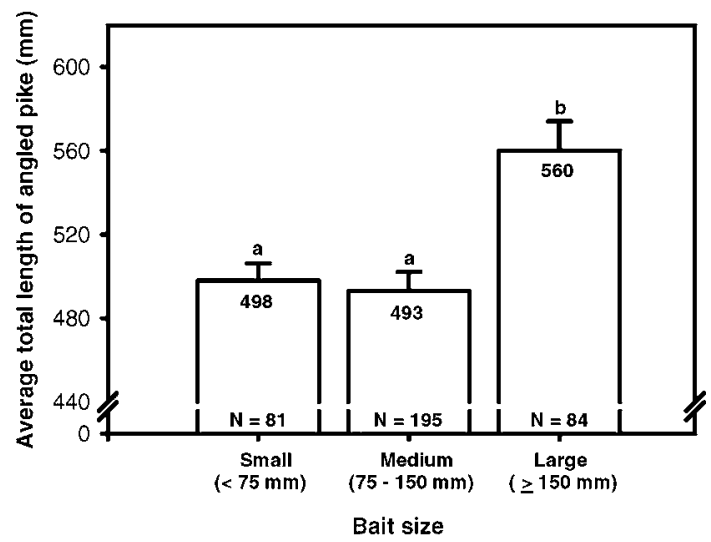

B

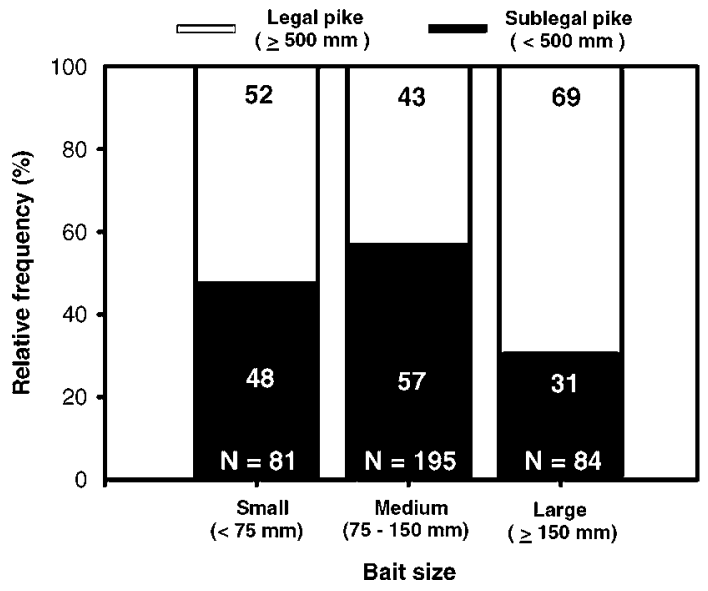

FIGURE 2.- Relation between bait size and (A) average size $(+\mathrm{SE})$ of angled northern pike in Lake Kleiner Döllnsee, Germany, and Lake Opinicon, Ontario, Canada (bars sharing the same letters are not significantly different; $N=$ sample size; numbers within the bars are actual values), or (B) relative frequency $(\%)$ of legal- and sublegal-sized northern pike.

Initial mortality was unrelated to bait type, bait size, fish size, fishing method, or hooking location (all $P>$ 0.05). The only significant variable was presence of bleeding $\left(\chi^{2}=46.44\right.$, df $=10, P<0.001,98.7 \%$ correctly classified cases. Contingency table analysis confirmed that mortality was related to presence of bleeding $\left(\chi^{2}=26.82\right.$, df $=1, P<0.001$; Figure 5). However, more than $80 \%$ of northern pike that exhibited some level of bleeding did not die immediately. Also, $71.4 \%$ of the fish hooked in the gills bled, but only $25 \%$ of all those hooked in the gills died initially (i.e., within $1 \mathrm{~h}$ ). 
TABLE 1.-Percentage of northern pike hooked in different locations relative to bait type used during recreational angling in Lake Kleiner Döllnsee, Germany and Lake Opinicon, Ontario. Values in parentheses are numbers of fish captured.

\begin{tabular}{lllllllr}
\hline & \multicolumn{4}{c}{ Non-critical hooking locations } & & \multicolumn{2}{c}{ Critical hooking locations } \\
\cline { 2 - 3 } Bait type & Lower jaw & Upper jaw & Lower and upper jaw & External & & Gill & Gullet \\
\hline Spinner & $45.7(16)$ & $34.3(12)$ & $2.9(1)$ & $5.7(2)$ & & $5.7(2)$ & $5.7(2)$ \\
Spoon & $41.4(41)$ & $30.3(30)$ & $7.1(7)$ & $6.1(6)$ & & $14.1(14)$ & $1.0(5)$ \\
Shad/jig & $23.7(18)$ & $59.2(45)$ & $1.3(1)$ & $2.6(2)$ & & $2.6(2)$ & $10.5(8)$ \\
Wobbler & $29.4(25)$ & $48.2(41)$ & $5.9(5)$ & $9.4(8)$ & & $7.1(6)$ & $0(0)$ \\
Natural bait & $28.2(11)$ & $41.0(16)$ & $0(0)$ & $7.7(3)$ & & $7.7(3)$ & $15.4(6)$ \\
All & $33.2(111)$ & $43.1(144)$ & $4.2(14)$ & $6.3(21)$ & & $8.1(27)$ & $5.1(17)$ \\
\hline
\end{tabular}

\section{Discussion}

In agreement with previous research in various predatory fish species in commercial long-lining and recreational angling (Orsi 1987; Løkkeborg 1990; Orsi et al. 1993; Wilde et al. 2003), we found that the size of northern pike captured by angling was a function of bait type and, to a greater extent, bait size. Moreover, a larger proportion of legal-sized northern pike was captured on natural bait than on all artificial lures. This finding is contrary to previous reports in Atlantic salmon Salmo salar (Warner 1976), walleye Sander vitreus (Payer et al. 1989), cutthroat trout Oncorhynchus clarkii (Pauley and Thomas 1993), striped bass Morone saxatilis (Nelson 1998), and Atlantic cod Gadus morhua (Løkkeborg 1990), for which the average size of fish caught was larger using artificial lures than using natural bait. However, contrary to Warner's (1976) and Payer et al.'s (1989) studies, the natural bait used in our study was characterized by the largest average size of all bait types used. This suggests that in this study, bait size rather than bait type is responsible for the observed differences in size of northern pike captured.

Positive relationships between bait size and northern pike size are consistent with prey-predator size relationships in northern pike (Nilsson and Brönmark 2000). Maximum prey size can reach half of the northern pike's length (Mittelbach and Persson 1998); as the northern pike grow, progressively larger prey are included in the diet, albeit smaller prey generally are not excluded (Juanes 1994). This large variability in predation upon differently sized prey may explain the many anecdotal reports from anglers that capture small northern pike on unusually large lures. Nevertheless, we found an increase in northern pike size and a decrease in sublegal-sized fish in the catch when baits larger than $150 \mathrm{~mm}$ were used. This fact is most probably related to gape size limitations of smaller northern pike and offers potential for influencing the size of fish captured by appropriate bait size choices, as advocated by Wilde et al. (2003). However, it is important to note that the largest sizes of baits employed in Lakes Kleiner Döllnsee and Opinicon were not the largest sizes used by northern pike anglers elsewhere, because the expected fish sizes were intermediate. Further studies should be conducted in northern pike populations characterized by larger average sizes to determine whether size selectivity becomes more pronounced with increasing bait and northern pike size. The size of northern pike did not differ across the different artificial lures used, despite substantial differences in mean size of these lures; this result suggests that other factors beyond size of the bait play an important role in determining the size selectivity of northern pike angling. Possibly, the lure's individual action and associated likely variation in apparent size influence the northern pike's decision to attack the prey and therefore ultimately influence size selectivity.

In this study, bait type and size also influenced hooking location and injury (bleeding). In agreement with previous research in various fish species (e.g.,

TABLE 2.-Percentage of northern pike hooked in different locations relative to bait size (small, $<75 \mathrm{~mm}$; medium, $\geq 75-150$ $\mathrm{mm}$; large, $\geq 150 \mathrm{~mm}$ ) used during recreational angling in Lake Kleiner Döllnsee, Germany, and Lake Opinicon, Ontario. Values in parentheses are numbers of fish captured.

\begin{tabular}{|c|c|c|c|c|c|c|}
\hline \multirow[b]{2}{*}{ Bait size } & \multicolumn{4}{|c|}{ Non-critical hooking locations } & \multicolumn{2}{|c|}{ Critical hooking locations } \\
\hline & Lower jaw & Upper jaw & Lower and upper jaw & External & Gill & Gullet \\
\hline Small & $39.4(26)$ & $28.8(19)$ & $4.5(3)$ & $6.1(4)$ & $15.2(10)$ & $6.1(4)$ \\
\hline Medium & $36.0(67)$ & $46.2(86)$ & $4.3(8)$ & $5.4(10)$ & $4.3(8)$ & $3.8(7)$ \\
\hline Large & $29.6(24)$ & $44.4(36)$ & $2.5(2)$ & $8.6(7)$ & $7.4(6)$ & $7.4(6)$ \\
\hline All & $35.1(117)$ & $42.3(141)$ & $3.9(13)$ & $6.3(21)$ & $7.2(24)$ & $5.1(17)$ \\
\hline
\end{tabular}




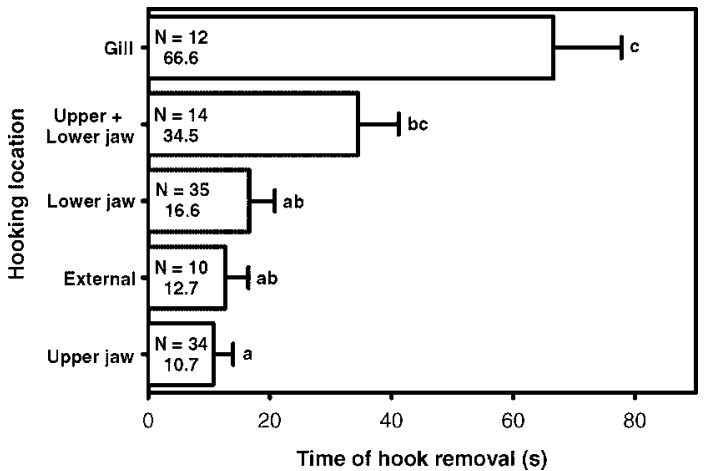

FIGURE 3.-Average (+SE) hook removal duration (s) relative to anatomical hooking location for recreationally angled northern pike in Lake Kleiner Döllnsee, Germany, and Lake Opinicon, Ontario, Canada (bars sharing the same letters are not significantly different; $N=$ sample size; numbers within the bars are actual values).

Clapp and Clark 1989; Payer et al. 1989; Persons and Hirsch 1994; Cooke et al. 2001) including northern pike (Beukema 1970; Tomcko 1997), we found that natural bait was swallowed more deeply than artificial baits, presumably because the striking fish recognized natural bait as a food source and thus was more likely to swallow the bait. We also found that hooking critical areas was more likely for soft plastic shads and spoons than for wobblers and spinners. Soft plastic shads resemble natural food more than other lures made out of wood, hard plastic, or steel and therefore might induce swallowing similar to natural baits. Natural baits and soft plastic shads also tended to be fished passively in this study, which may facilitate deep hooking compared with active natural bait fishing (Schill 1996; Schisler and Bergersen 1996; Nelson 1998).

Hooking location in northern pike was also influenced by the size of the lure. This finding contrasts with Burkholder (1992), who found that the type of hook (single, single treble, and double treble hook, all fished with artificial lures) did not influence hooking location, although baits with double treble hooks should be larger than lures equipped with single hooks. We found that frequency of deep hooking increased with decreasing bait size, probably because it was easier for a northern pike to swallow smaller bait. This is consistent with the literature on other freshwater species, such as largemouth bass (Clapp and Clark 1989), rock bass (Cooke et al. 2001), and bluegill (Siewert and Cave 1990). Depth of hook penetration delays or even prohibits hook removal and may increase the potential for damaging vital organs

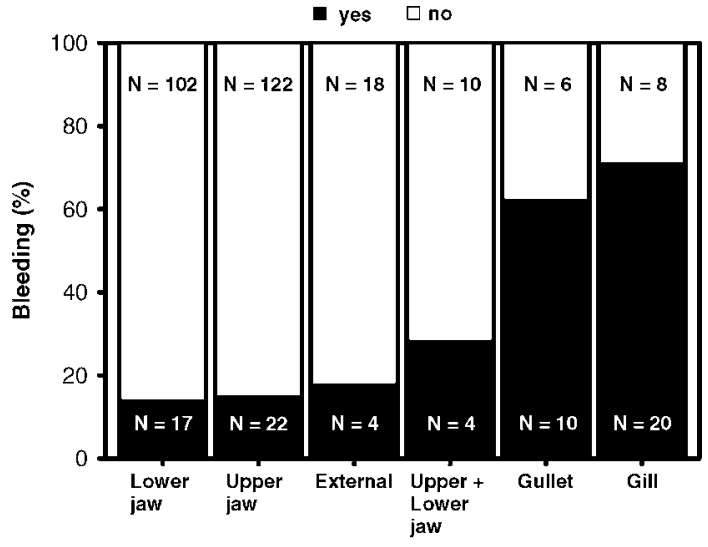

Hooking location

FIGURE 4.-Bleeding frequency relative to anatomical hooking location for recreationally angled northern pike in Lake Kleiner Döllnsee, Germany, and Lake Opinicon, Ontario, Canada $(N=$ sample size $)$.

(Tomcko 1997; Tsuboi et al. 2006; Arlinghaus et al. 2007a).

The critical role of hooking location in leading to lethal and sublethal effects of catch-and-release angling in northern pike was emphasized by the following results: (1) deep hooking increased the likelihood of bleeding, (2) hooking in the gills increased handling time to remove the hook, and (3) presence of bleeding increased the likelihood of initial mortality. These patterns are consistent with previous reports on a variety of species (e.g., Warner and Johnson 1978; Siewert and Cave 1990; Pauley and Thomas 1993;

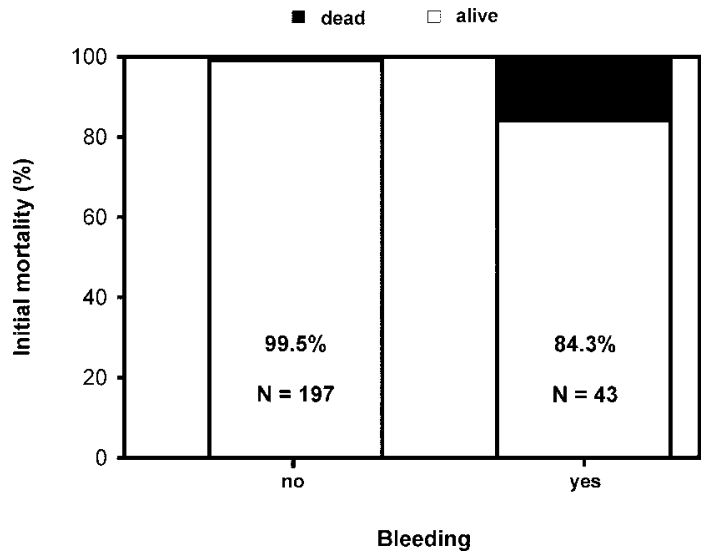

FIGURE 5.-Relationship between bleeding incidence and initial mortality (\%) of caught-and-released northern pike in Lake Kleiner Döllnsee, Germany, and Lake Opinicon, Ontario, Canada ( $N=$ sample size; numbers within the bars are percentages of fish that survived). 
Schisler and Bergersen 1996; Nelson 1998; Cooke et al. 2001; Dunmall et al. 2001; Lindsay et al. 2004; Meka 2004; Cowen et al. 2007). Depth of hooking increases hook removal times, which may influence a suite of physiological disturbances associated with prolonged air exposure duration (Cooke et al. 2001; Cooke and Suski 2005; Arlinghaus et al. 2007a). However, northern pike are resilient to air exposure for up to 240 s (DuBois et al. 1994; Burr 1998). This resiliency, however, only relates to mortality after release. The impact of air exposure on postrelease behavior or physiology of northern pike is currently unknown.

The frequency of bleeding as a result of hooking was unrelated to fish size, bait type, bait size, or fishing method; instead, it was exclusively related to hooking location. Similarly, earlier research by Burkholder (1992) found that northern pike hooked in the gills bled more often than those hooked on other locations, and bleeding was more likely for fish caught on small treble hooks than for fish caught on three other hook configurations. DuBois et al. (1994) also reported that bleeding of northern pike after capture was related to hook type and hooking location. We found that hooking location influenced bleeding in northern pike and, in turn, bleeding increased the likelihood of initial mortality. Similarly, DuBois et al. (1994) reported that mortality was greater for deeply hooked northern pike and for those that bled. However, it is also important to recognize that deep hooking is not necessarily related to bleeding in northern pike and bleeding northern pike do not necessarily die (DuBois et al. 1994). For example, in our study $28.6 \%$ of northern pike hooked in the gills and $37.5 \%$ of those hooked in the gullet did not bleed at all, and $80 \%$ of those that bled did not exhibit immediate mortality. Also, $71.4 \%$ of the northern pike hooked in the gills bled, but only $25 \%$ of all the individuals hooked in the gills were observed mortalities. For comparative purposes, Pauley and Thomas (1993) found that $95.5 \%$ of all gill-hooked cutthroat trout died, and Nelson (1998) reported increasing mortalities with increasing degree of bleeding from $33 \%$ in slightly bleeding striped bass to $75 \%$ in heavily bleeding striped bass. It appears that northern pike are rather robust to injury associated with capture by both lures and natural bait, which is supported by previous observations of this species (Weithman and Anderson 1978; Tomcko 1997).

Initial mortality of northern pike was very low (2.4 $\pm 1.5 \%$ ) even though the study was conducted during the summer months, when water temperatures were high. Elevated water temperatures are known to increase catch-and-release mortality (Munoeke and Childress 1994; Cooke and Suski 2005; Arlinghaus et al. 2007a). However, there is the caveat that delayed mortality might have occurred in our study but went unnoticed. In fact, two moribund northern pike were observed in Lake Döllnsee by the research team and were identified (as part of a separate tagging study) as individuals captured by angling and released $2 \mathrm{~d}$ before. Therefore, the hooking mortality rate reported here has to be considered an underestimate, as delayed mortality was not accounted for (Pollock and Pine 2007). Although most postrelease mortality will probably occur in the short term (within the first 24$48 \mathrm{~h}$ in most species; Munoeke and Childress 1994), the 1-h observation period in this study was made for expediency given the large sample size. Furthermore, there were no control fish in our study design, which further reduces the accuracy of the mortality estimate presented (Pollock and Pine 2007). However, lack of controls overestimates hooking mortality, whereas omitting delayed mortality underestimates it. Hence, the presented initial hooking mortality estimate constitutes the major limitation of our study. Nevertheless, the low initial hooking mortality estimate agrees with previous research for northern pike (average hooking mortalities $<5 \%$, weighted across studies; Tomcko 1997). It is therefore unlikely that the true value differed substantially (e.g., $>10 \%$ ) from the estimate we determined.

Reasons for the low initial mortality rate might be related to the experimental procedures applied. For example, the research team comprised experienced northern pike anglers, so bites on natural bait were immediately countered with a strike (i.e., swallowing of natural bait was minimized) and no effort was made to unhook deeply hooked fish. Instead, hooks were quickly cut by a wire cutter whenever deep hooking or hooking in the gills was observed; this practice is common among highly specialized northern pike anglers (authors' personal observations). Previous research has determined that the removal of deeply ingested hooks resulted in a higher risk of mortality in Atlantic salmon (Warner 1979), rainbow trout $O$. mykiss (Mason and Hunt 1967), white seabass Atractoscion nobilis (Aalbers et al. 2004), and whitespotted char Salvelinus leucomaenis (Tsuboi et al. 2006). This supports the view that it is preferable to avoid attempting to remove hooks if deeply ingested by northern pike and to either leave them inside (not studied so far in northern pike) or cut the barbed shanks of the hooks with a wire cutter. Meka (2004) reported that novice anglers injured proportionally more fish than experienced anglers. This might particularly apply in northern pike angling, as inexperienced anglers may lack wire cutters, pliers, and similar devices helpful for unhooking fish (DuBois et al. 1994) and might fear 
personal injury when handling large individuals with sharp teeth. Collectively, this may result in extreme caution among inexperienced northern pike anglers when attempting to remove deeply hooked lures and baits (Newman and Storck 1986), possibly inducing higher injury and damage through mucus abrasion and air exposure in most practical northern pike fisheries than reported here.

Our study showed that (1) the size of northern pike was positively related to lure or bait size, (2) the amount of deep hooking was inversely related to lure or bait size, (3) natural bait was more deeply ingested than artificial baits, (4) the time of hook removal and the bleeding frequency were higher for deeply hooked fish, and (5) bleeding increased initial mortality. Overall, the study results agree with those of Wilde et al. (2003) in that lure size and type regulations can complement standard harvest regulations. Anglers can influence the size of fish captured by choosing specific bait types and bait sizes. For example, capture of legalsized fish is more likely when using natural baits and large bait sizes. In a catch-and-release angling context, anglers can reduce level of injury and deep hooking by using larger baits and specific artificial lures, such as spinners and wobblers. To protect large northern pike in biomanipulation programs (see Mehner et al. 2004) or another management context, restrictions on the use of natural bait could be an effective strategy. This, however, highlights the complexities of using lure and bait regulations to complement standard harvest regulations. For example, whereas the use of natural bait might reduce the percentage of sublegal-sized northern pike captured, it might also result in higher incidences of deeply hooked, bleeding fish that are more likely to experience hooking mortality. To avoid or minimize hooking mortality and hooking-related injury, northern pike anglers need to be educated about proper fishing and handling techniques, which may involve cutting the barbed shanks of hooks with a wire cutter when fish are deeply hooked and striking quickly when fishing with natural bait. This would minimize hooking mortality and injury to the fish, protect an important fisheries resource, and contribute to enhanced fish welfare in a catch-and-release context (Arlinghaus et al. 2007b).

\section{Acknowledgments}

We thank Alexander Türck for excellent technical assistance and many German anglers, too numerous to name, for their help during field work. We also thank the staff of Queen's University Biological Station for facilitating this research activity in Canada. Volunteer anglers in Canada included Andrew Gingerich (Baby Waschbär), Kyle Hanson, and Mike Donaldson. Work in Germany was approved through an animal care permit granted by the Ministry for Rural Development, Environment, and Consumer Protection, Brandenburg, according to the German Animal Protection Act. Work in Canada was approved by the Canadian Council on Animal Care through the Carleton University Animal Care Committee (Application B06-04). Funding for this project was provided by the German Academic Exchange Service (Deutscher Akademischer Austausch Dienst) through an international master of science grant to T.K.; the Leibniz-Institute of Freshwater Ecology and Inland Fisheries; the Leibniz-Community within the Adaptfish Project (www.adaptfish.igb-berlin.de); the Canadian Foundation for Innovation; the Natural Sciences and Engineering Research Council; the Rainy Lake Fisheries Charity Trust; and Carleton University. Comments by three anonymous reviewers and the associate editor improved the manuscript.

\section{References}

Aalbers, S. A., G. M. Stutzer, and M. A. Drawbridge. 2004. The effects of catch-and-release angling on the growth and survival of juvenile white seabass captured on offset circle and J-type hooks. North American Journal of Fisheries Management 24:793-800.

Arlinghaus, R. 2007. Voluntary catch-and-release can generate conflict within the recreational angling community: a qualitative case study of specialised carp, Cyprinus carpio, angling in Germany. Fisheries Management and Ecology 14:161-171

Arlinghaus, R., S. J. Cooke, J. Lyman, D. Policansky, A. Schwab, C. Suski, S. G. Sutton, and E. B. Thorstad. 2007a. Understanding the complexity of catch-andrelease in recreational fishing: an integrative synthesis of global knowledge from historical, ethical, social, and biological perspectives. Reviews in Fisheries Science 15:75-167.

Arlinghaus, R., S. J. Cooke, A. Schwab, and I. G. Cowx. 2007b. Fish welfare: a challenge to the feelings-based approach, with implications for recreational fishing. Fish and Fisheries 8:57-71.

Arlinghaus, R., and T. Mehner. 2004. A managementorientated comparative analysis of urban and rural anglers living in a metropolis (Berlin, Germany). Environmental Management 33:331-344.

Armstrong, D. W., R. S. T. Ferro, D. N. MacLennan, and S. A. Reeves. 1990. Gear selectivity and the conservation of fish. Journal of Fish Biology 37(Supplement A):261262.

Bartholomew, A., and J. A. Bohnsack. 2005. A review of catch-and-release angling mortality with implications for no-take reserves. Reviews in Fish Biology and Fisheries 15:129-154.

Benndorf, J. 1995. Possibilities and limits for controlling eutrophication by biomanipulation. Internationale Revue der Gesamten Hydrobiologie 80:519-534.

Beukema, J. J. 1970. Acquired hook avoidance in the pike Esox lucius L. fished with artificial and natural baits. Journal of Fish Biology 2:155-160. 
Burkholder, A. 1992. Mortality of northern pike captured and released with sport fishing gear. Alaska Department of Fish and Game, Division of Sport Fish, Fishery Data Series 92-3, Anchorage.

Burr, J. 1998. Effect of post-capture handling on mortality in northern pike. Alaska Department of Fish and Game, Division of Sport Fish, Fishery Data Series No. 98-34. Anchorage.

Clapp, D. F., and R. D. Clark, Jr. 1989. Hooking mortality of smallmouth bass caught on live minnows and artificial spinners. North American Journal of Fisheries Management 9:81-85.

Cooke, S. J., B. L. Barthel, C. D. Suski, M. J. Siepker, and D. P. Philipp. 2005. Influence of circle hook size on hooking efficiency, injury, and size selectivity of bluegill with comments on circle hook conservation benefits in recreational fisheries. North American Journal of Fisheries Management 25:211-219.

Cooke, S. J., D. P. Philipp, K. M. Dunmall, and J. F. Schreer. 2001. The influence of terminal tackle on injury, handling time, and cardiac disturbance of rock bass. North American Journal of Fisheries Management 21:333-342.

Cooke, S. J., and H. L. Schramm. 2007. Catch-and-release science and its application to conservation and management of recreational fisheries. Fisheries Management and Ecology 14:73-79.

Cooke, S. J., J. F. Schreer, K. M. Dunmall, and D. P. Philipp. 2002. Strategies for quantifying sub-lethal effects of marine catch-and-release angling: insights from novel freshwater applications. Pages 121-134 in J. A. Lucy and A. L. Studholme, editors. Catch and release in marine recreational fisheries. American Fisheries Society, Symposium 30, Bethesda, Maryland.

Cooke, S. J., and C. D. Suski. 2005. Do we need speciesspecific guidelines for catch-and-release recreational angling to effectively conserve diverse fishery resources? Biodiversity and Conservation 14:1195-1209.

Cowen, L., N. Trouton, and R. E. Bailey. 2007. Effects of angling on Chinook salmon for the Nicola River, British Columbia, 1996-2002. North American Journal of Fisheries Management 27:256-267.

Craig, J. F. 1996. Pike: biology and exploitation. Chapman and Hall, London.

DuBois, R. B., T. L. Margenau, R. S. Stewart, P. K. Cunningham, and R. W. Rasmussen. 1994. Hooking mortality of northern pike angled through ice. North American Journal of Fisheries Management 14:769-775.

Dunmall, K. M., S. J. Cooke, J. F. Schreer, and R. S. McKinley. 2001. The effect of scented lures on the hooking injury and mortality of smallmouth bass caught by novice and experienced anglers. North American Journal of Fisheries Management 21:242-248.

Eckmann, R. 1995. Fish species richness in lakes of the northeastern lowlands in Germany. Ecology of Freshwater Fish 4:62-69.

Falk, M. R., and D. V. Gillman. 1975. Mortality data for angled Arctic grayling and northern pike from the Great Slave Lake area, Northwest Territories. Canada Fisheries and Marine Service Data Report Series CEN-D-75.

Fayram, A. H. 2003. A comparison of regulatory and voluntary release of muskellunge and walleyes in northern Wisconsin. North American Journal of Fisheries Management 23:619-624.

Grimm, M. 1981. [The surviving chances of caught and released pikes]. Organisation of $r$ the Improvement of Freshwater Fisheries Report 1:1-11. (In Dutch.)

Juanes, F. 1994. What determines prey size selectivity in piscivorous fishes? Pages 79-100 in D. J. Stouder, K. L. Fresh, and R. J. Feller, editors. Theory and application in fish feeding ecology. Belle W. Baruch Library of Marine Sciences, University of South Carolina Press, Columbia.

Keast, A., J. Harker, and D. Turnbull. 1978. Nearshore fish habitat utilization and species associations in Lake Opinicon (Ontario, Canada). Environmental Biology of Fishes 3:173-184.

Klefoth, T. 2007. Behaviour of pike (Esox lucius) in response to angler-induced disturbance in a catch-and-release fishery in Lake Kleiner Döllnsee. Master's thesis. Humboldt-University of Berlin, Germany.

Kobler, A. 2007. Habitatwahl und Aktivität des Hechtes (Esox lucius L.) im Keinen Döllnsee: eine radiotelemetrische Untersuchung. Master's thesis. Hohenheim University, Stuttgart, Germany.

Lindsay, R. B., R. K. Schroeder, and K. R. Kenaston. 2004. Hooking mortality by anatomical location and its use in estimating mortality of spring Chinook salmon caught and released in a river sport fishery. North American Journal of Fisheries Management 24:367-378.

Løkkeborg, S. 1990. Reduced catch of under-sized cod (Gadus morhua) in longlining by using artificial bait. Canadian Journal of Fisheries and Aquatic Sciences 47:1112-1115.

Mason, J. W., and R. L. Hunt. 1967. Mortality rates of deeply hooked rainbow trout. Progressive Fish-Culturist 29:8791.

Mehner, T., R. Arlinghaus, S. Berg, H. Dörner, L. Jacobsen, P. Kasprzak, R. Koschel, T. Schulze, C. Skov, C. Wolter, and K. Wysujack. 2004. How to link biomanipulation and sustainable fisheries management: a step-by-step guideline for lakes of the European temperate zone. Fisheries Management and Ecology 11:261-275.

Meka, J. M. 2004. The influence of hook type, angler experience, and fish size on injury rates and the duration of capture in an Alaskan catch-and-release rainbow trout fishery. North American Journal of Fisheries Management 24:1309-1321.

Mittelbach, G. G., and L. Persson. 1998. The ontogeny of piscivory and its ecological consequences. Canadian Journal of Fisheries and Aquatic Sciences 55:1454-1465.

Mosindy, T. E., W. T. Momot, and P. J. Colby. 1987. Impact of angling on the production and yield of mature walleyes and northern pike in a small boreal lake in Ontario. North American Journal of Fisheries Management 7:493-501.

Munoeke, M. I., and W. M. Childress. 1994. Hooking mortality: a review for recreational fisheries. Reviews in Fisheries Science 2:123-156.

Nelson, K. L. 1998. Catch-and-release mortality of striped bass in the Roanoke River, North Carolina. North American Journal of Fisheries Management 18:25-30.

Newman, D. L., and T. W. Storck. 1986. Angler catch, growth, and hooking mortality in small centrarchiddominated impoundments. Pages 346-351 in G. E. Hall, 
editor. Managing muskies: a treatise on the biology and propagation of muskellunge in North America. American Fisheries Society, Special Publication 15, Bethesda, Maryland.

Nilsson, P. A., and C. Brönmark. 2000. Prey vulnerability to a gape-size limited predator: behavioural and morphological impacts on northern pike piscivory. Oikos 88:539_ 546.

Orsi, J. A. 1987. Small versus large trolling lures for sampling juvenile Chinook salmon and coho salmon. Transactions of the American Fisheries Society 116:50-53.

Orsi, J. A., A. C. Wertheimer, and H. W. Jaenicke. 1993. Influence of selected hook and lure types on catch, size, and mortality of commercially troll-caught Chinook salmon. North American Journal of Fisheries Management 13:709-722.

Paukert, C. P., J. A. Klammer, R. B. Pierce, and T. D. Simonson. 2001. An overview of northern pike regulations in North America. Fisheries 26(6):6-13.

Pauley, G. B., and G. L. Thomas. 1993. Mortality of anadromous coastal cutthroat trout caught with artificial lures and natural bait. North American Journal of Fisheries Management 13:337-345.

Payer, R. D., R. B. Pierce, and D. L. Pereira. 1989. Hooking mortality of walleyes caught on live and artificial baits. North American Journal of Fisheries Management 9:188-192.

Persons, S. E., and S. A. Hirsch. 1994. Hooking mortality of lake trout angled through ice by jigging and set-lining. North American Journal of Fisheries Management 14:664-668.

Pierce, R. B., C. M. Tomcko, and D. H. Schupp. 1995. Exploitation of northern pike in seven small north-central Minnesota lakes. North American Journal of Fisheries Management 15:601-609.

Pollock, K. H., and W. E. Pine III. 2007. The design and analysis of field studies to estimate catch-and-release mortality. Fisheries Management and Ecology 14:123130.

Radomski, P. J., G. C. Grant, P. C. Jacobson, and M. F. Cook. 2001. Visions for recreational fishing regulations. Fisheries 26(5):7-18.

Schill, D. J. 1996. Hooking mortality of bait-caught rainbow trout in an Idaho trout stream and a hatchery: implications for special-regulation management. North American Journal of Fisheries Management 16:348-356.
Schisler, G. J., and E. P. Bergersen. 1996. Postrelease hooking mortality of rainbow trout caught on scented artificial baits. North American Journal of Fisheries Management 16:570-578.

Schwalme, K., and W. C. Mackay. 1985. The influence of angling-induced exercise on the carbohydrate metabolism of northern pike (Esox lucius L.). Journal of Comparative Physiology B 156:67-75.

Siewert, H. F., and J. B. Cave. 1990. Survival of released bluegill, Lepomis macrochirus, caught on artificial flies, worms, and spinner lures. Journal of Freshwater Ecology 5:407-411.

Tomcko, C. M. 1997. A review of northern pike Esox lucius hooking mortality. Minnesota Department of Natural Resources Section of Fisheries, Fish Management Report 32, St. Paul.

Tsuboi, J., K. Morita, and H. Ikeda. 2006. Fate of deep-hooked white-spotted charr after cutting the line in a catch-andrelease fishery. Fisheries Research 79:226-230.

Warner, K. 1976. Hooking mortality of landlocked Atlantic salmon, Salmo salar, in a hatchery environment. Transactions of the American Fisheries Society 105:365-369.

Warner, K. 1979. Mortality of landlocked Atlantic salmon hooked on four types of fishing gear at the hatchery. Progressive Fish-Culturist 41:99-102.

Warner, K., and P. R. Johnson. 1978. Mortality of landlocked Atlantic salmon (Salmo salar) hooked on flies and worms in a river nursery area. Transactions of the American Fisheries Society 107:772-775.

Weithman, A. S., and R. O. Anderson. 1978. Angling vulnerability of Esocidae. Proceedings of the Annual Conference Southeastern Association of Fish and Wildlife Agencies 30(1976):99-102.

Wilde, G. R. 1998. Tournament-associated mortality in black bass. Fisheries 23(10):12-22.

Wilde, G. R. 2003. Estimation of catch and release fishing mortality and its sampling variance. Pages $83-85$ in A. P. M. Coleman, editor. Regional experiences for global solutions: proceedings of the 3 rd world recreational fishing conference. Department of Business, Industry and Resource Development, Fisheries Group, Fisheries Report 67, Darwin, Australia.

Wilde, G. R., K. L. Pope, and B. W. Durham. 2003. Lure-size restrictions in recreational fisheries. Fisheries 28(6):1826. 